\title{
Pan Indian Presence of RISHI MARKANDEY --- Glimpses into his Life, Victory over Death, Sites Associated with him, and Tips for Longevity and well being
} Dr. Sharadendu Bali ${ }^{1 *}$

${ }^{1}$ Professor General Surgery, MMIMSR, Mullana, Ambala, Haryana, India

DOI: $10.36347 /$ sjahss.2021.v09i05.004

| Received: 07.04.2020 | Accepted: 11.05.2021 | Published: 15.05.2021

*Corresponding author: Dr. Sharadendu Bali

\section{Abstract}

The concept of One Nation in the vastly diverse population that inhabits the Indian sub-continent, is unique among world civilizations. This feeling of nationalism is as old as the Vedas, and was inculcated and nurtured by some ancient seers and saints. Foremost among them is Rishi Markandeya, whose imprint is not just found all over the Indian landmass, but also traverses all the way to Indonesia and Bali. Markandey is also unique among seers because he is venerated among all the mainstream Indian religious traditions, namely Vaishnavism, Shaivism, Devi cults and ascetic orders. From his birth in the Himalayas, to his severe penance in the dense jungles of the Western Ghats of peninsular India, to the ashrams along the Narmada and Ganges, and going upto the Eastern coast at Jagannath Puri, the Indian sub-continent is strewn with sites named after the great Rishi. The present paper attempts to list out some of these sites, and the accompanying geographical features, in an effort to highlight the immense accomplishments of the Rishi, encompassing fields as diverse as geology, hydrology, philosophy, herbal medicine, music, sacred chanting, goddess worship, astrology and horticulture.

Keywords: One Nation, world civilizations, nationalism, Indian religious traditions, Western Ghats.

Copyright $\odot 2021$ The Author(s): This is an open-access article distributed under the terms of the Creative Commons Attribution 4.0 International License (CC BY-NC 4.0) which permits unrestricted use, distribution, and reproduction in any medium for non-commercial use provided the original author and source are credited.

\section{INTRODUCTION}

Out of all the Rishies of yore, Rishi Markandey stands distinguished as the only one with a Purana named after him. He is also unique for his lifestory, wherein from being ill-fated to die at the age of sixteen years, he attained to immortality as a result of his severe penance. Markandey thus deflected the foul swoop of the messengers of death, leaving for us to ponder and decipher the mechanisms and modalities thereof. He is one of the seven chiranjeevis (immortals), as given in various scriptures [1]. The others are: Ashwatthama, Hanuman, Kripacharya, Ved Vyas, Parashuram and Vibhishana.

\section{BIRTH PLACE}

The site of the birth place of Markandey is at village Markand Makri in district Bilaspur in Himachal Pradesh. (Bilaspur is a distorted version of Byas-pur, named after Rishi Ved Vyas.) This village is supposed to have been the abode of rishi Mrikandu, the father of Markandey. It is around $20 \mathrm{kms}$ by road from Bilaspur town, but is around $5 \mathrm{kms}$. by trek up and down the mountain which separates Markanda from Bilaspur. At Bilaspur, along the sloping banks of River Satluj, is located the Vyas cave(gupha) which is supposed to have been a meditation spot of Muni Ved Vyas, the author of the Puranas and the Mahabharata.

In fact, Markandey was a disciple of Mahamuni Ved Vyas. According to folk-lore, the Vyas cave at Bilaspur goes right through the mountain and across to Markand Makri, a distance which would be around $4-5 \mathrm{kms}$. At Markanda also there is a cave marked as Vyas gupha, which is the other end of the tunnel. The great characteristic of Markand Makri, located in a valley, is the large number of water sources or springs which abound in the vicinity. These springs are said to be curative for skin disorders, and newly weds often come here to take a bath in the holy spring. The idol of Rishi Markandey at this temple is of a clean-shaven youth, since the rishi is said to have gained immortality at adolescence and hence never grew older. The site of the springs is crowned by a string of Banyan trees, and the entrance of the cave is also located right below the Banyans.

There are a total of five spots in the vicinity associated with Rishi Markandey.

These are: Bati Krishan, Indra dhoun or Indra-daman, Mahodadhi, Rohini and Markanda. 
Sharadendu Bali., Sch J Arts Humanit Soc Sci, May, 2021; 9(5): 168-174

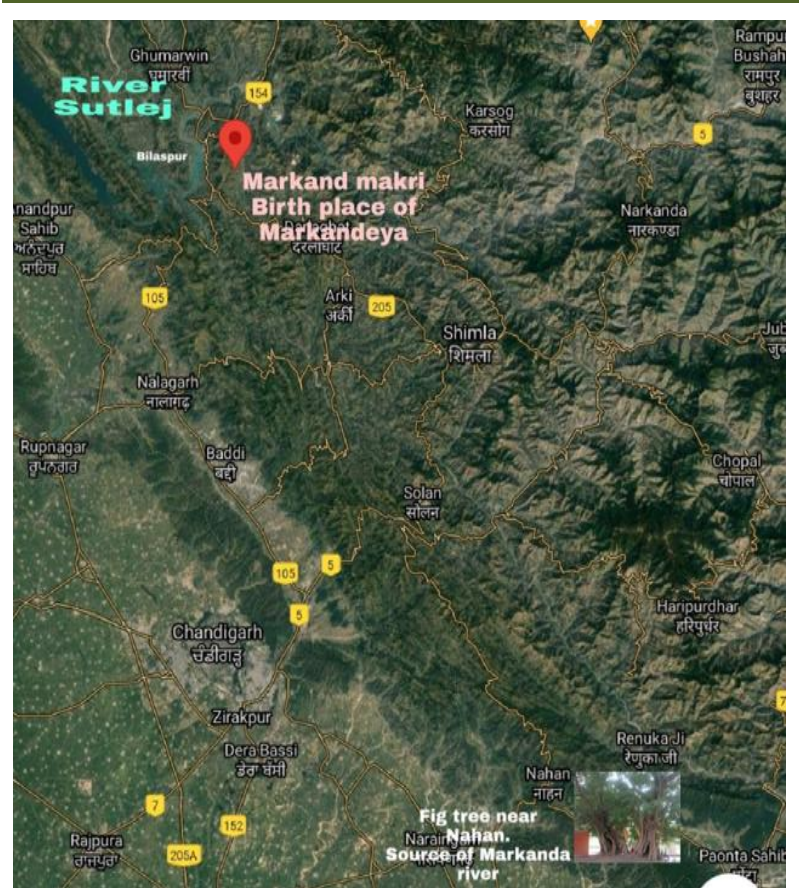

Fig-1:Map showing location of Markand Makri, the birth place of Rishi Markanda, in District Bilaspur, Himachal Pradesh.( Location is marked with red pointer). Location of Fig tree near Nahan is also shown in right bottom corner of map. Markanda river arises from the roots of this gigantic fig (Pakhar) tree.

All these spots have water sources from which water collects in pools (kunds) before being channeled off. Bati Krishan has the maximum water discharge, and the kund is situated at the base of a Peepal tree. A few decades earlier, the amount of water springing out is said to have been much more. The sub-terraneal fresh water is pumped out from near here to surrounding towns.

\section{ASSOCIATED SITES IN NORTH INDIA}

All in all, the association of Rishi Markandey with water is incontrovertible. This will be established beyond doubt in this paper; since all the sites associated with Rishi Markandey are sources of copious amounts of fresh water. It is thus extremely plausible that having mastered the science of hydrology and geology, the rishi was able to create new springs at points where he found such sources possible and feasible. Haridwar being the most important religious centre in North India, most ascetics and sadhus visit it at one time or the other. This is especially so at times of Kumbh. It sounds logical that Rishi Mrikandu and his son would have also travelled to Haridwar at times of these religious gatherings.

If we consider the route which Markandey would have taken to travel from Bilaspur to Haridwar, it will have gone via Solan and Nahan to the Bata valley. From there onwards via Ponta Sahib to Haridwar. It is precisely at a point on this route that the rishi carried out immense tapasya in order to make the Goddess Saraswati appear from the roots of the Plaksh tree. This is at Bohliyo village near Jogi Ban just off the Kala Amb-Ponta Sahib route. Also known as Plaksh-prasar vana, this place has several sources of water, out of which three are from the roots of Plaksh trees. And the perrenial spring arising from the ancient huge fig tree forms the source of the Markanda river (considered to be the Saraswati) [2].

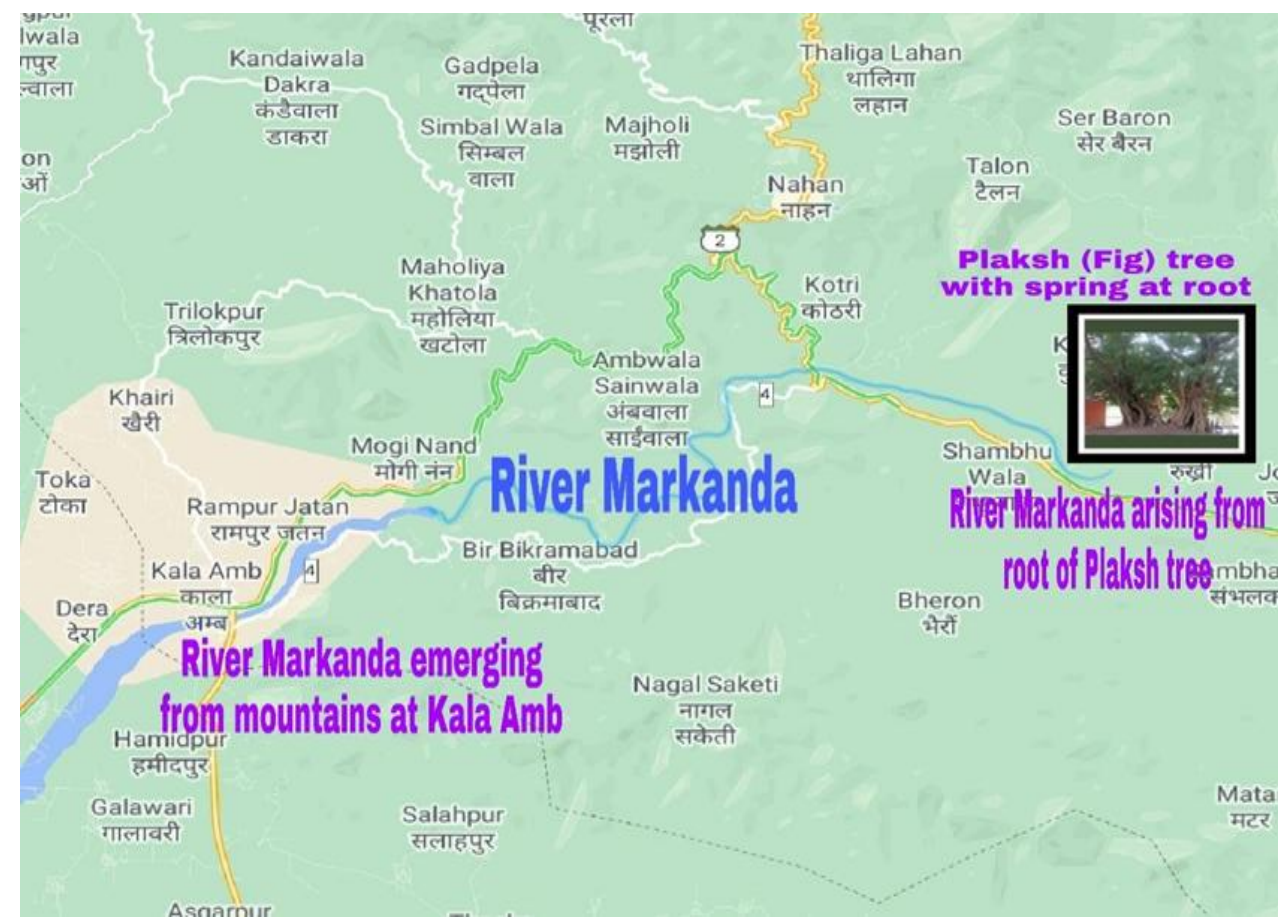

Fig- 2: Map showing point of origin of River Markanda, from the spring arising from the roots of the Pakhar (Fig) tree near Nahan. 

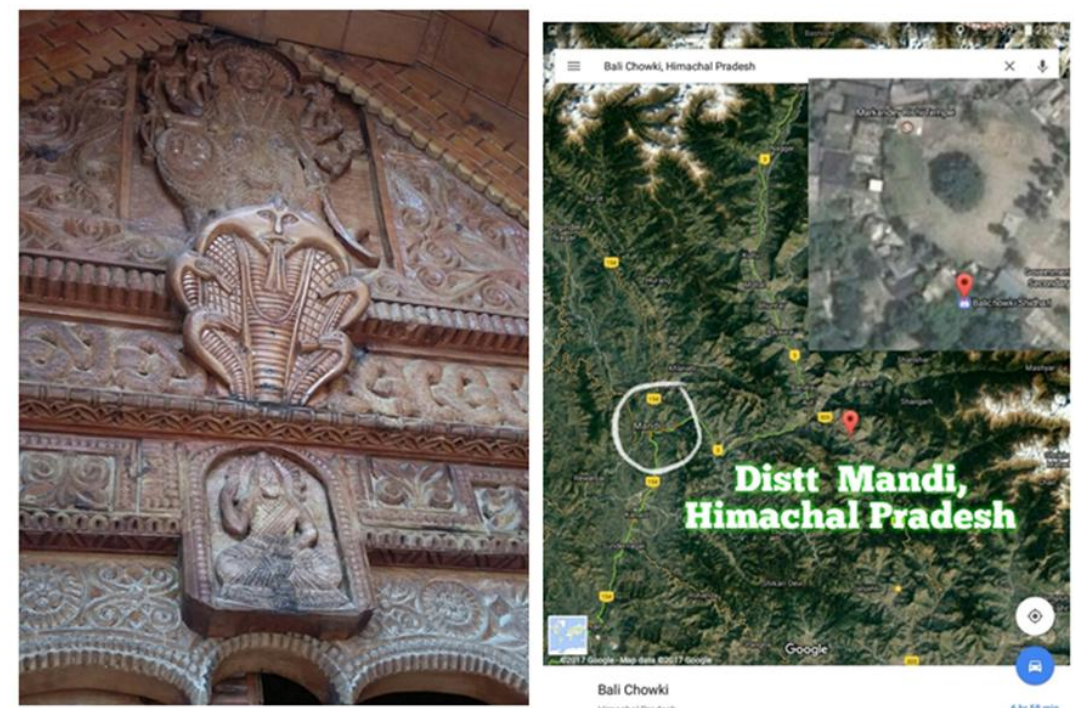

Fig-3: Wooden sculpture at the doorway of Markanda temple, Bali chowki. The temple is located on top of a mountain near the village of Bali chowki in Mandi district HP. (Bali chowki is marked with red pointer, and Mandi city is encircled in white.)

There are several other sites where ancient temples dedicated to Rishi Markandey exist. Districts Mandi and Kulu in Himachal Pradesh abound in such temples, many of them located on top of high mountains. In Banjar tehsil, sub tehsil Bali Chowki, for instance, there are at least four such temples. And alongwith the main temples, the Rishi Devta also has his other abodes of residence known as Kothis. Most of these temples are made entirely of wood, and are intricately carved. Fairs are held at these temples on specific days every year, when local people climb up the steep mountains to worship the rishi. On the occasion of Shiv ratri, the devta's idol is carried on palanquin to Kulu, the site where all the demi-gods congregate for the festival.

\section{Markanda ashram near Yamunotri}

En route to the Himalayan source of the Yamuna, from Hanuman chatti, on trekking along the left bank of the river, one comes across the ashram of Markandey. About $25 \mathrm{kms}$ from Varanasi, at the confluence of the rivers Gomti and Ganga, is located an ancient temple of Markandey Mahadev (Figure 4).

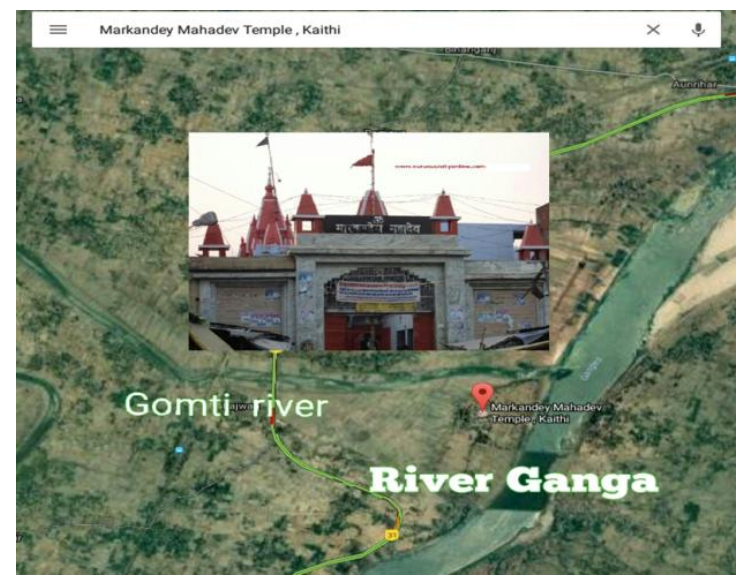

Fig4: Markandeya temple in Benares district of Uttar Pradesh.

\section{MYTHOLOGY}

In the Markandey Purana, the narrative begins with Sage Jaimini approaching Rishi Markandeya to ask him the details of the Mahabharata war. But the rishi had evening oblations to attend to and due to paucity of time, advised Jaimini to get the details from four birds living in the Vindhya mountains. Jaimini was astonished to learn about birds that could talk, and asked Rishi Markandeya to explain the mystery behind this extraordinary ability of the birds [3].

Markandey rishi narrated the story as follows:

The four birds are sons of Drona, the bird king. While the great Mahabharata war was going on, their mother Tarakshi was flying over the battlefield at three and a half months of pregnancy. Suddenly an arrow shot by Arjuna got deflected upwards and pierced Tarakshi, splitting open her abdomen. The four eggs she was carrying slipped out and hit the ground where the battle was raging. Surprisingly, the eggs were intact, and at that very instant the huge bell around the neck of the elephant Suprateek belonging to Bhagdatt got untethered and landed atop the eggs, enclosing them from all around.

It was in this protected casing of the bell that the four eggs survived the battle skirmishes that went on all around them, till they eventually hatched. Rishi Shamik was passing by one day when he heard the screeches coming from the giant bell. He ordered his pupils to lift the bell, and lo behold, on doing so they were all astonished to see the four chicks, alive and well. The Rishi nurtured the chicks till they attained full growth, and at this stage the birds spoke to the rishi," Sir, you have looked after us from the time we were famished and starving. Please tell us how we can serve you." Shamik rishi was astonished to find the birds talking to him, and asked them the reason of this unusual ability. The birds the narrated their story thus: 
Sharadendu Bali., Sch J Arts Humanit Soc Sci, May, 2021; 9(5): 168-174

Rishi Sukrish had four sons. One day Devraj Indra visited the ashram in the guise of an old vulture. In the tradition of a good host, the sage asked the huge vulture how he could be of service, and agreed to provide whatever was asked for. Indra the vulture asked for some human flesh to satiate his hunger. The ascetic called his four sons and asked them to provide some piece of flesh from their bodies for the guest. All four declined, upon which the sage was furious and cursed them to be born as flesh eating avians in their next birth. Thereafter, the sage performed his own last rites and offered his body to the vulture. Indra reappeared and lauded the sage. But the rishi would not relent upon his curse and subsequently the four were born as sons of the bird Drona.

Drona was married to Tarakshi, who was also born as a bird because of a curse by rishi Durvasa. It so happened that once when Devarishi Narada visited Lord Indra, the latter introduced him to the celestial nymphs and asked him to choose anyone to present a dance performance. Narada said he would choose the one who was able to distract the great Muni Durvasa from his meditation. The apsara Vapu agreed and managed to distract Rishi Durvasa, who whereupon cursed her to be reborn a bird.

So we can see the great Importance accorded to the holy Narmada river in the Markandey Purana. In fact the Rishi meditated on the sacred river, using her other name - Reba. It may be noted that the Narmada flows west-wards, similar to the west flowing Saraswati. The Holy Narmada arises near Amarkantak, at a place known as the Narmada udgam, where there is a small kund or tank (Figure 5). Around a kilometer from this spot is the Markandey Ashram. At Omkareshwar also, on the banks of the Narmada, there is a Markandey ashram.

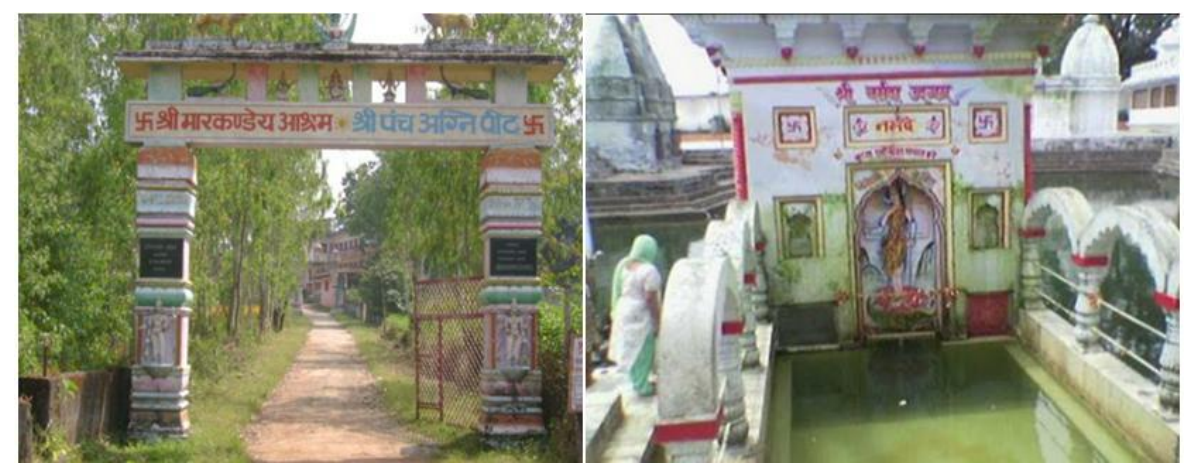

Fig-5: Left - Source of River Narmada, a spring near Amarkantak in Chhatisgarh. On the right is the Markandeya Ashram, close to the origin of the Narmada

The story of the conquest of Markandey over the God of Death is fascinating. Markandey was the son of Mrikandu who was in the lineage (descendant) of Sage Bhrigu. When Mrikandu and his wife could not bear a son for long time, they prayed to Lord Shiva to grant them the boon of a son. When Lord Shiva appeared, he gave the couple a choice ---- either a highly intelligent and dedicated son who would live only upto the age of sixteen, or a long lived but indifferent son. The couple chose the former, but after his birth, as the age of doom approached, became increasingly morose. On being questioned by Markandey about the cause of the distress, the parents disclosed the truth. Markandey reassured them and took their permission to proceed to meet up with learned rishies in order to find a solution [4].

Accordingly, Markandey went to a place known as Ballivat van (in Kurukshetra, at Brahma tirth in Thana) where several rishies including his grandfather Bhrigu were doing penance. On being informed by Markandey about his plight, and asked for advice to be released of this, Maharishi Bhrigu instructed the young lad to proceed to the Tungabhadra river and pray to Lord Hari under the tree known as Bhadra-vat [2]. The young seer did as instructed, and prayed with total dedication to the Lord Vishnu, who protected him and shooed away the messengers of Death when they tried to approach Markandey. Rishi Markandeya thus attained immortality. This whole narrative is given in the Narsingh Puraná. The site where Markandey prayed on the banks of the river Bhadra is today known as Bhadravati. The temple located on the Bhadra river is known as the Kandya temple (Figure 6). Rivers Bhadra and Tungabhadra join to forming the Tungabhadra. 


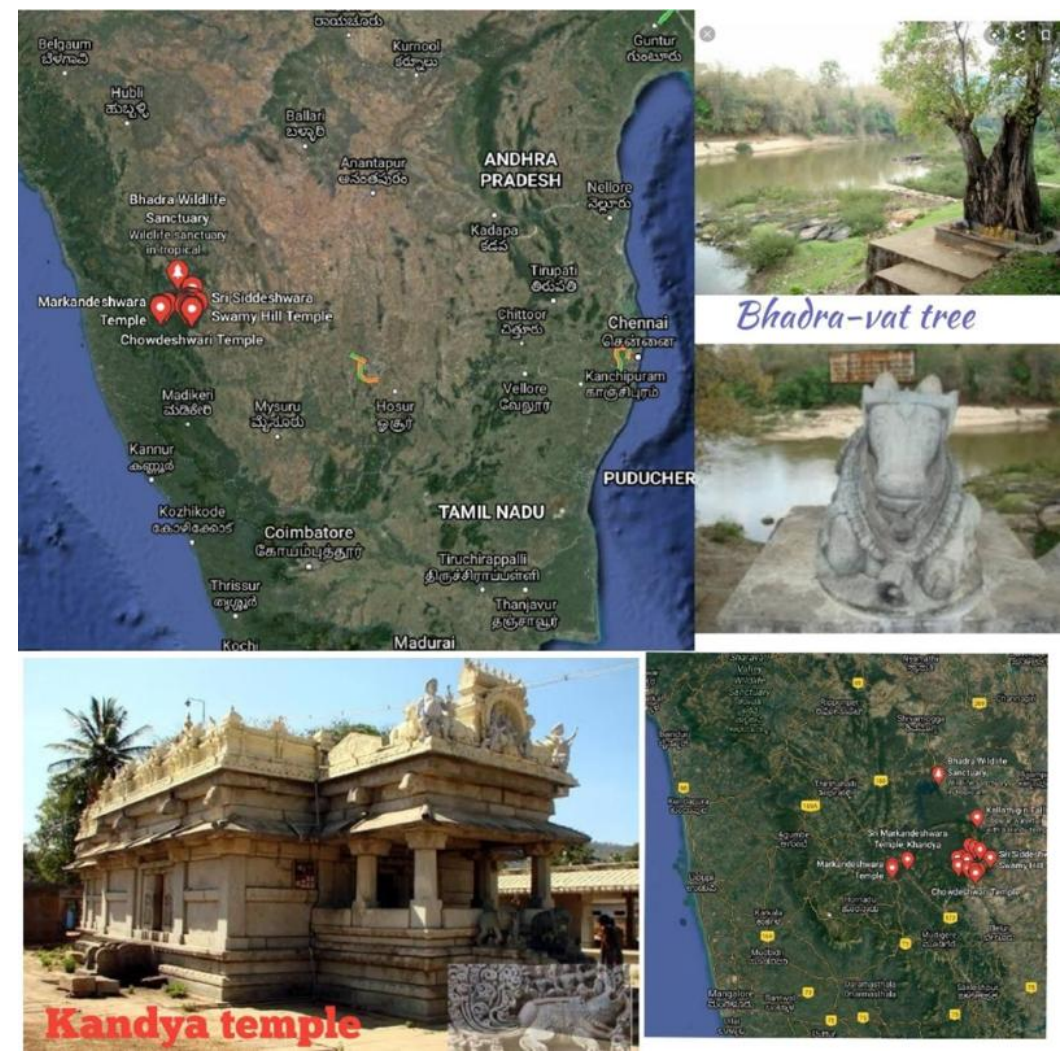

Fig-6: The Kandya temple located in the densely wooded western ghats, south of Shiva-moga. Top right is the Balli-vat, the banyan tree under which Rishi Markandeya meditated on the banks of the Bhadra river.

\section{OTHER SITES IN PENINSULAR INDIA}

Since Markandeya travelled the entire Bharat varsha from North to south, it is obvious he would have seen the enchantingly changing landscapes as they unfolded during his long travels over many thousands of kilometres. He must have also visited numerous pilgrimage spots and seers during his arduous tours. The immense learning that he possessed alongwith the power of his intellect must have influenced the populace all along this route. This probably explains the antiquity of the temples and ashram named after him, along the north-south axis of the Indian subcontinent. There are thus exquisitely sculpted rock-cut temples in Maharashtra, Karnataka and Tamil Nadu named after him.

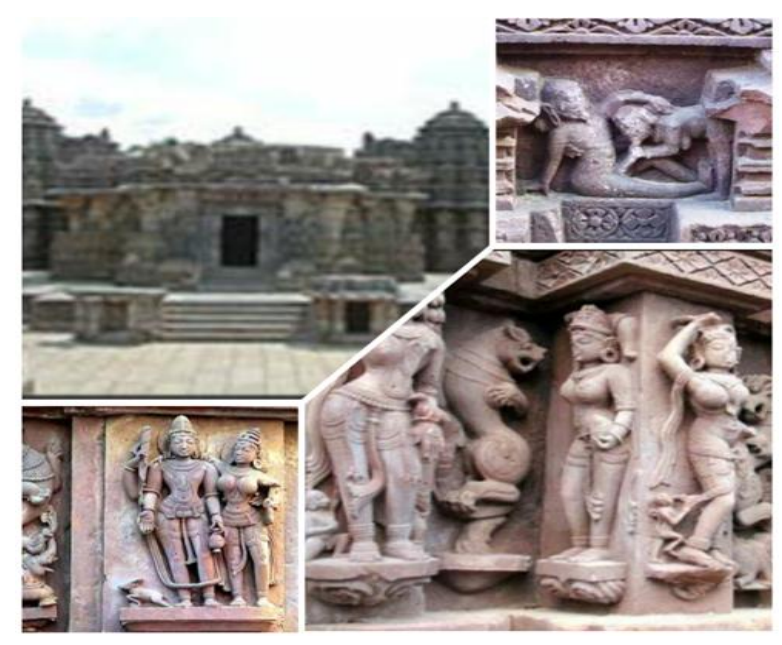

The huge, majestically laid out and beautifully sculpted temple at Gadchiroli in Maharashtra is located on the banks of the Wainganga. (see images ) This long river has well formed alluvial plains and joins the river Prana-hita, which joins the Godavari. The name Prana- hita means beneficial to health and life. The exquisitely carved sculptures at the Markandey devasthanam at Chamorshi also include some images of erotic art. This temple was the pride of Vidarbha at one time and was known as Kashi of Vidarbha. 
Sharadendu Bali., Sch J Arts Humanit Soc Sci, May, 2021; 9(5): 168-174

The Markandeshwar Gudi temple and rock cut inscriptions at Kallur near Raichur in Karnataka is one more majestic temple named after the immortal sage. There are beautifully sculpted polished pillars of granite. The temple is located at the Base of one of three rocky hills and has a fort-like entrance. The location is not far from the river Tungabhadra. The structure of the temple is not pure rock, since the upper portions are made of mortar and bricks. There is also a serpent sculpture in the temple premises.

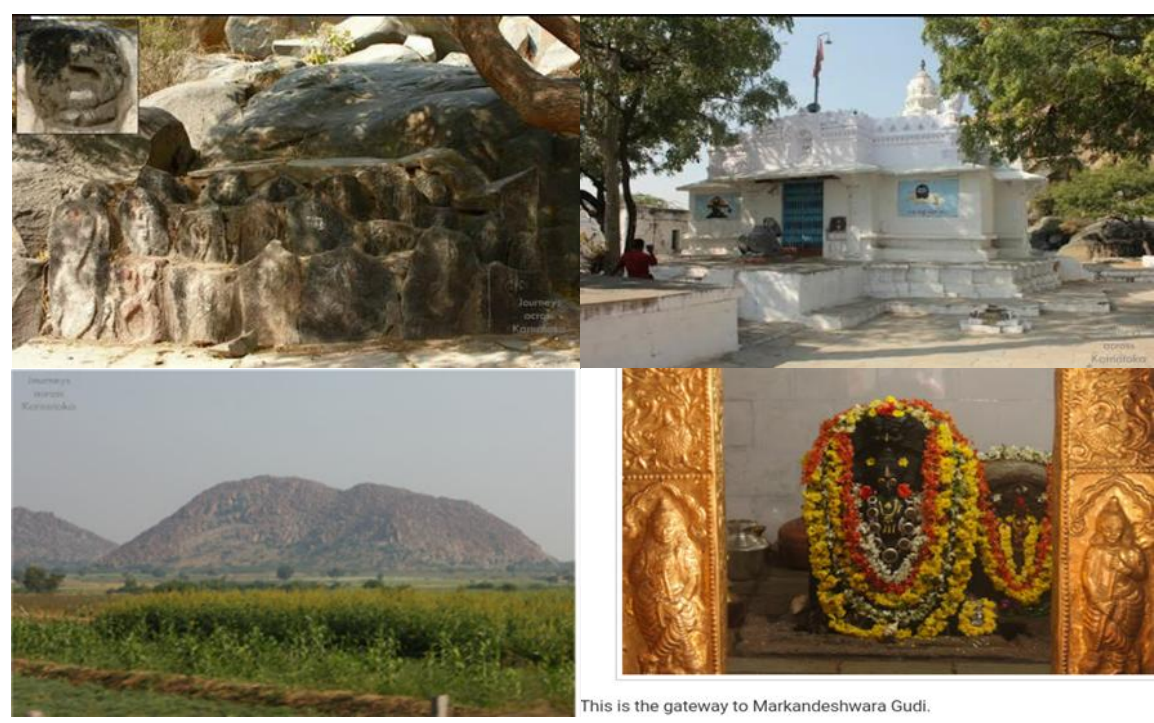

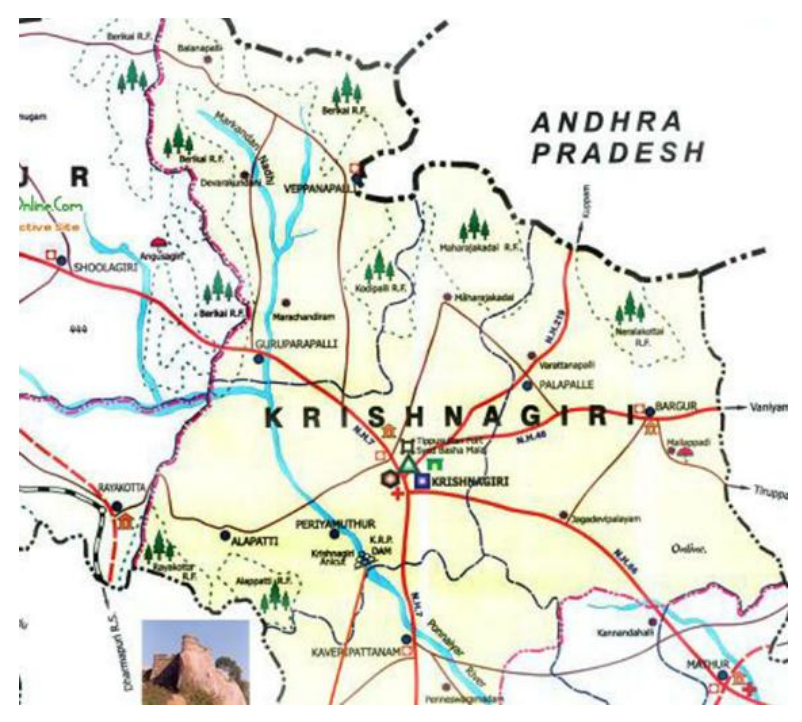

In Tamil Nadu is located the river Markandey, a tributary of the south Pennar river in district Krishnagiri is the river Markanda. This is a very ancient inhabited area and forms the traditional gateway to Tamil Nadu. There are ancient rock carvings in this district which show distinct linkages to the Industry valley civilization. The ancient GOLD mining site of Kolar is just north of the river. The area has numerous other ancient linkages to several rishies, suggesting that this was the site of civilization in Vedic era. Some examples are Sharbhang rishi, Sanat kumas --- There are rivulets named after these sages. Maharishi Markandey is credited with having espoused the Mahamrityunjaya mantra, although Rishi Vashisht is also part of the formulations of this vedic mantra.

\section{Mahamritunjaya Mantra}

This highly enigmatic Mantra was revealed to Markandeya and only he is supposed to fully understand the subtle nuances of the verses. The powerful Mantra is considered potent enough to ward off illness and even death, and Markandey had for sure, warded off the God of Death Yama. When Chandra the moon God had been cursed by his father-in-law Daksha, Markandey had initiated the former into chanting the verses to mollify the effects of the curse. As a result, Chandra escaped destruction but had to undergo periods of waxing and waning to survive.This wondrous Mantra finds mention in three vedas--- Rig vela, Yajur veda and Atharva-veda.
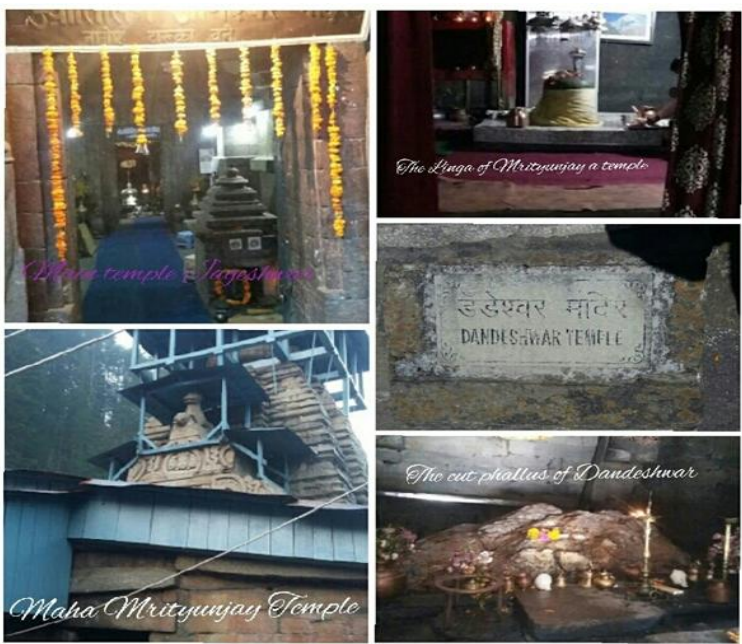

The Mahamritunjaya temple at Jageshwar ---This is the largest temple in the complex of over one hundred ancient temples made of rock. The sanctum has 
Sharadendu Bali., Sch J Arts Humanit Soc Sci, May, 2021; 9(5): 168-174

a huge lingam. The story behind the temple at Jageshwar and nearby Dandeshwar is about the dismemberment of Shiva's phallus, a bloody and gory event which could have possibly only been rectified with the use of the powerful Mantra, hence the pride of place accorded to the temple named after the Mantra. The locale of the temple complex at Jageshwar (Nagesh jyotirling) is a dense forest of Devdar trees, which is the source of the word "daruka-van".

\section{Markandeya in the Indus Valley civilization}

Amongst the thousands of seals excavated from the sites of the Indus-Saraswati, is one depicting the story of Markandeya. This seal is numbered M DK 6747 and depicts the boon of Shiva bestowed on Markandeya [5].

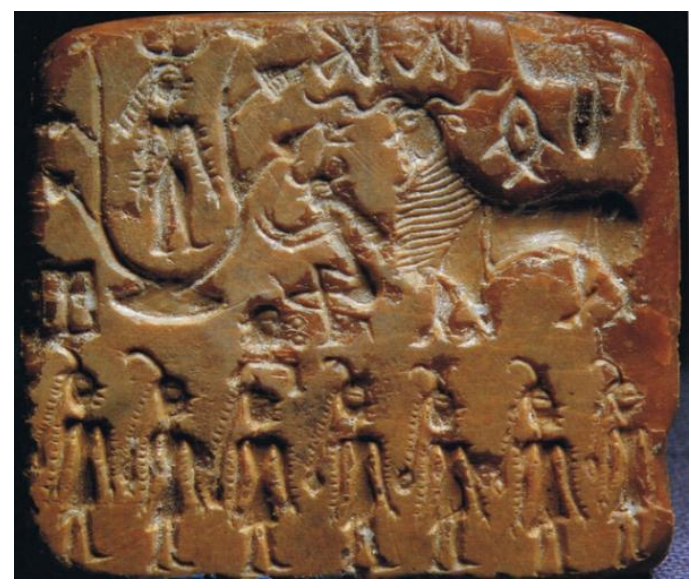

\section{Markandeshwar Temple at Puri}

At Jagannath Puri in Orissa , at the very heart of the Sri kshetra, is located the very ancient Markandeshwar temple, said by many to have been constructed by the sage himself in the worship of the Great God, Mahadeva. Markandeya is venerated in all the mainstream Hindu denominations, and established the Shiva temple at the Vaishnavite shrine at Puri to create harmony between the Shaiva and Vaishnava sects.
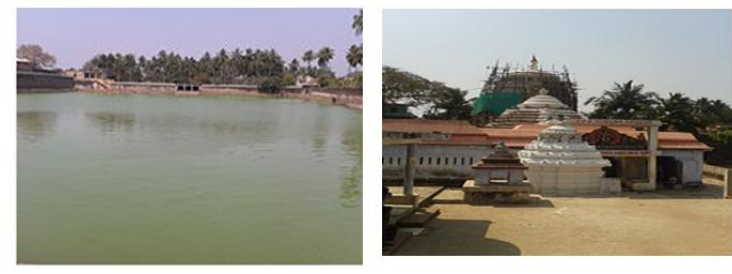

Markandeshwar Tank

The main shrine of Lord Jagannath is surrounded by eight temples called Ashta-shambhus; Markandeshwar is one of them.It is located around half a kilometer from the main shrine, and is situated beside the large (four acre) Markandeshwar tank. This tank is one of the panch tirthas, or five holy tanks. And here lies the great mystery--- the names coincide with the five water sources named at Markanda Makri, the birth place of the Rishi.These five sites are: Indra-dhyumna, Rohini, Mahodadhi and Krishna,alongwith Markanda temple itself.

It is astonishing to say the least, that the four names are the same, though geographically the two locations are two thousand miles apart. And the names make little sense to the local people. Mahodadhi stands for ocean, and there are prayers in this name.Dhaun means neck in Punjabi, and Indra's neck is one possibility, though there was a king of that name in Orissa in the era gone by.Indra and Mahodadhi are associated with surplus water just like Sage Markanda. All the sites linked to Markandey are located next to perennial water bodies. He was a master of hydrology and could determine accurately the sources of subterranean water, a priceless skill in all ages and locations.

The river Markanda which arises in the Shivaliks is a source of gold dust when it flows during the monsoons. The other river of same name in Tamil $\mathrm{Nadu}$ also arises near the largest gold fields in India, Kolar.The Mahamrityunjaya Mantra also mentions gold (rukmi) to be tied to the thigh.This signifies the immense importance of gold in health. Fragrance is also hinted at leading to good health, in the words of the Mahamrityunjaya mantra - sugandi pushti vardhanam (good smell enhances health). Residing along the banks of a river also has health benefits, since it is recognized that flowing waters are therapeutic.

The story of Rishi Markandey is highly inspiring, alongwith being thought-provoking. The panIndian presence and reverence accorded to sages like Markandeyan, has been at the very root of the birth of the conception of India as a nation. Even though the Indian sub-continent has ever been politically fragmented, the concept of national conciousness survived the vagaries and ravages of time - until the final political re-unification 70 years back. This miracle of unity in diversity can easily be traced back to the foundations laid by great sages like Markanda.

\section{REFERENCES}

1. https://en.m.wikipedia.org/wiki/Chiranjivi

2. Bali,S. (2015). Geographical source of the Vedic River Saraswati and authentication from the scriptures. The Indian Journal of Research, Volume 9, Number 1, pg 18-26.

3. Markandeya purana sanshipt. Gita press Gorakhpur. Chapter1, 2 and 3.

4. Shri Narsingh Purana, Gita Press Gorakhpur.Chapter 7.

5. http://harappansymbolsandscripts.blogspot.com/20 18/04/indus-seal-m-dk-6847-reveals-boon-of.html. 